\title{
Correction to: Ethics and Sustainability in Accounting and Finance, Volume II
}

\author{
Kıymet Tunca Çalıyurt
}

\section{Correction to:}

K. T. Çalıyurt (ed.),

Ethics and Sustainability in Accounting and Finance, Volume

II, Accounting, Finance, Sustainability, Governance \&

Fraud: Theory and Application, https://doi.org/10.1007/978-981-15-1928-4

The original version of the book was published with incorrect authors affiliation in the chapter 3 and in Front matter "Acknowledgements" text are updated.

The correction chapter and book have been updated with the changes. 